\title{
TUMPUROO AS A LOCAL COMMUNITY HEALTH WORKER TO SUPPORT FOR FAMILY WITH CHILDREN UNDER FIVE
}

\author{
Early Wulandari Muis \\ National Population and Family Planning Agency, Southeast Sulawesi
}

\begin{abstract}
Background: Every year, an estimated 11 million children in developing countries die before they reach their fifth birthday. Mortality of children under the age of five remains one of the most important public health challenges in developing countries. In rural settings, the promotion of household and community health practices through community health workers (CHWs) is among the key strategies to improve child health. This study aimed to describe "tumpuroo" as a local community health worker to support for family with children under five.

Subjects and Method: A qualitative study carried out in Rawa Aopa Watumohai National Park, Bombana, Sulawesi Tenggara. Key informants were selected, including custom figure (tumpuroo), government officers, and a representative from the National Coordinating Board of Family Planning (BKKBN). The study theme was "tumpuroo" as a local community health worker to support for family with children under five. The data were collected by observation and in-depth interview.

Results: BKKBN had an ideal parenting model, namely Bina Keluarga Balita (BKB). But its implementation was not optimal. The program did not reach population in the remote inland areas such as Tobu Hukaea-Laeya. Tumpuroo as an element within the traditional structure took its role as a local community health worker in the BKB program. The way tumpuroo delivered health education was unique by singing a lyric, namely "mo'odulele".

Conclusion: Tumpuroo has an important role in the remote inland community, which can be capitalized to help deliver health promotion and education to improve population health.
\end{abstract}

Keywords: Tumpuroo, inland community, health promotion, education, parenting, children.

\section{Correspondence:}

Early Wulandari Muis. National Population and Family Planning Agency, Jl. Abunawas, Kadia, Pondambea, Kota Kendari, Southeast Sulawesi.

Email: earlywm_kdio4@yahoo.com. Mobile: 08114091304.

The 4th International Conference on Public Health

Best Western Premier Hotel, Solo, Indonesia, August 29-30, 2018 | 202 https://doi.org/10.26911/theicph.2018.03.33 